This is a preprint of a paper intended for publication in a journal or proceedings. Since changes may be made before publication, this preprint is made avalable with

the understanding that it $w_{1} l l$ not be cited or reproduced

UCRL -72087

without the permission of the author.

\title{
PREPRINT
}

\section{CONF. TOOIOI-I}

Inawemoe Fadiation Iaboxatory

LIVERMORE

\section{MASITR}

\author{
POSSIBLE TECHNIQUES FOR DECONTAMINATION
}

OF NATURAL GAS FROM GAS WELLS STIMULATED

BY A NUCLEAR EXPLOSION

John A. Wethington, Jr.

October 1, 1969

This manuscript was prepared for publication in the Proceedings of the American Nuclear Society Meeting on Engineering with Nuclear Explosives, Las Vegas, Nevada, January 14-16, 1970. 


\section{DISCLAIMER}

This report was prepared as an account of work sponsored by an agency of the United States Government. Neither the United States Government nor any agency Thereof, nor any of their employees, makes any warranty, express or implied, or assumes any legal liability or responsibility for the accuracy, completeness, or usefulness of any information, apparatus, product, or process disclosed, or represents that its use would not infringe privately owned rights. Reference herein to any specific commercial product, process, or service by trade name, trademark, manufacturer, or otherwise does not necessarily constitute or imply its endorsement, recommendation, or favoring by the United States Government or any agency thereof. The views and opinions of authors expressed herein do not necessarily state or reflect those of the United States Government or any agency thereof. 


\section{DISCLAIMER}

Portions of this document may be illegible in electronic image products. Images are produced from the best available original document. 
POSSIBLE TECHNIQUES FOR DECONTAMINATION

OF NATURAL GAS FROM GAS WELLS STIMULATED BY A NUCLEAR EXPLOSION

John A. Wethington, Jr.

Lawrence Radiation Laboratory, University of California

Livermore, California 94550

October 1, 1969 


\title{
POSSIBLE TECHNIQUES FOR DECONTAMINATION \\ OF NATURAL GAS FROM GAS WELLS STIMULATED BY A NUCLEAR EXPLOSION
}

\author{
John A. Wethington, Jr. \\ Lawrence Radiation Laboratory, University of California \\ Livermore, California 94550
}

\begin{abstract}
A BSTRACT
Decontamination of the products from gas wells stimulated by nuclear explosions requires the removal of $\mathrm{T}$, present as $\mathrm{HT}, \mathrm{CH}_{3} \mathrm{~T}, \mathrm{C}_{2} \mathrm{H}_{5} \mathrm{~T}$, etc., and $85 \mathrm{Kr}$ from the production stream. Flaring of large volumes of gas from the Gasbuggy well led to the replacement of radioactive cavity gas with inactive formation gas, but this would not be a satisfactory production procedure because it releases $\mathrm{T}$ and ${ }^{85} \mathrm{Kr}$ into the atmosphere and wastes large amounts of product gas. Exchange reactions appear to offer promise for removing the tritium. For example, water or steam flowing countercurrent to tritiated gas in the presence of a suitable catalyst can participate in the exchange reactions

$$
\begin{aligned}
& \mathrm{CH}_{3} \mathrm{~T}+\mathrm{H}_{2} \mathrm{O}=\mathrm{CH}_{4}+\mathrm{HTO}, \\
& \mathrm{HT}+\mathrm{H}_{2} \mathrm{O}=\mathrm{H}_{2}+\mathrm{HTO},
\end{aligned}
$$

resulting in the transfer of $T$ from gas into water. Other possibilities for utilizing exchange reactions include exchange of the gas with ethylene glycol used in the gas dryer, with silicate rocks introduced into the gas stream, or with a countercurrent stream of $\mathrm{NH}_{3}$ or $\mathrm{H}_{2} \mathrm{~S}$. As another approach, use of the contaminated gas for the manufacture of ammonia synthesis gas has potential for removal of both $\mathrm{T}$ and $85 \mathrm{Kr}$.
\end{abstract}

\section{INTRODUCTION}

Radiochemical data on gas obtained from the Gasbuggy well after nuclear stimulation have been complled by Smith ${ }^{1}$; the se data show that the only significant radioactive contamination results from $\mathrm{T}$ and $85 \mathrm{Kr}$. The former is present mainly as $\mathrm{HT}$ and $\mathrm{CH}_{3} \mathrm{~T}$ with lesser amounts of $\mathrm{C}_{2} \mathrm{H}_{5} \mathrm{~T}$ and $\mathrm{C}_{3} \mathrm{H}_{7} \mathrm{~T}$. Flaring of the well has produced significant decreases in the radioactivity level of the gases, but this procedure is undesirable on a production scale since it releases radioactivity into the biosphere, wastes large quantities of marketable gas, and interrupts the normal production in the distribution system. Better methods of decontaminating the gas are needed.

The quantities of gas involved and the economic structure of the industry seem to require that any chemical or physical process used for decontamination have a large throughput and employ inexpensive or reusable process materials. Thise requirements suggest using some combination of the isotope effect, exchange reactions, and/or gas-liquid extraction processes. This report examines some possible decontamination techniques and outlines a proposed program of studies aimed at developing a satisfactory production procedure.

*Permanent address: University of Florida, Gainesville, Florida 32601. 
$\underline{\text { Equilibrium }}$

Mass differences affect the energy of molecules, and for the hydrogen isotopes, these energy differences are large; consequently, the distribution of hydrogen isotopes among several molecular species at equilibrium is far from random. Isotopes of heavier elements, on the other hand, tend to be randomly distributed among the various possible molecular species. Representative values are shown in Table I.

Table I. Equilibrium distribution of selected isotopes, illustrating large departure from random distribution in isotopes of lighter elements.

\begin{tabular}{lc}
\hline \multicolumn{1}{c}{ Reaction } & $\left(\mathrm{K} / \mathrm{K}^{\prime}\right)^{\mathrm{a}}$ at $298.1^{\circ} \mathrm{K}$ \\
\hline $\mathrm{HT}+\mathrm{H}_{2} \mathrm{O} \rightleftharpoons \mathrm{H}_{2}+\mathrm{HTO}$ & 6.194 \\
$\mathrm{HD}+\mathrm{H}_{2} \mathrm{O}=\mathrm{H}_{2}+\mathrm{HDO}$ & 3.703 \\
$\mathrm{HC} 1+\mathrm{DI}=\mathrm{DC} 1+\mathrm{HI}$ & 1.527 \\
$13 \mathrm{CO}_{2}+{ }^{12} \mathrm{CO}_{3} \rightleftharpoons{ }^{12} \mathrm{CO}_{2}+{ }^{13} \mathrm{CO}_{3}$ & 1.012 \\
$13{ }^{1}{ }_{\mathrm{I}}{ }^{2} \mathrm{I}+127 \mathrm{I}_{3}^{-}=127_{\mathrm{I}_{2}}+129_{\mathrm{I} \mathrm{O}}^{-}$ & 1.002 \\
\hline
\end{tabular}

$a_{K}$ is the true equilibrium constant calculated from Urey's ${ }^{2}$ summary of partition functions, and $\mathrm{K}^{\prime}$ is the equilibrium constant from random distribution of isotopes.

\section{$\underline{\text { Kinetics }}$}

Isotopic molecules also undergo chemical transformation at different rates, and Bigeleisen ${ }^{3}$ has estimated from statistical rate theory the maximum isotope effect on rate constants. These results, summarized in Table II, show clearly that separation of the hydrogen isotopes by differences in reaction rate is highly favored over such separation methods for heavier molecules; consequently a separation can be accomplished by using equilibrium values, kinetic effects, or a combination of the two.

Table II. Ratio of specific rate constants $\left(\mathrm{k}_{1} / \mathrm{k}_{2}\right)$ at $25^{\circ} \mathrm{C}$ for selected isotope pairs (abstracted from Ref. 4).

\begin{tabular}{ccc}
\hline Isotope 1 & Isotope 2 & $\mathrm{k}_{1} / \mathrm{k}_{2}$ \\
\hline $\mathrm{H}$ & $\mathrm{D}$ & 18 \\
$\mathrm{H}_{1}$ & $\mathrm{~T}_{\mathrm{C}}$ & 60 \\
$16 \mathrm{O}$ & $13 \mathrm{C}$ & 1.25 \\
$127_{\mathrm{I}}$ & $131_{\mathrm{I}}$ & 1.19 \\
& & 1.02 \\
\hline
\end{tabular}

Exchange Reactions

$\underline{\text { Mechanism }}$

Why do exchange reactions take place? The mechanism for many such reactions is not known, but in general, the rate-determining step is one of the following:

1. The reversible dissociation of one reactant to give a product that may exchange rapidly with the second reactant. 
2. The decomposition of a transition state in which one or more electrons may be transferred from one reactant to the other.

3. The decomposition of a transition state in which one or more atoms may be transferred from one reactant to another.

This study is concerned with mechanism 3, illustrated by the exchange between halide ion and halogen, the trihalide ion presumably being the transition state as shown in the reaction

$$
\mathrm{X}_{2}+\mathrm{X}^{*-} \rightleftharpoons\left(\mathrm{X}_{3}^{*}\right)^{-} \rightleftharpoons \mathrm{X}^{-}+\mathrm{X}_{2}^{*}
$$

It should be clearly understood that this work is not concerned with the Wilzbach 5 labeling whivh is commonly used to label organic compounds with $\mathrm{T}$ by means of the following radiation-induced reaction:

$$
\mathrm{CH}_{4}+\mathrm{T}_{2} \leadsto \rightarrow \mathrm{CH}_{3} \mathrm{~T}+\text { other labeled products. }
$$

Certainly reaction (2) will take place in addition to the expected exchange reactions, but it will not be considered here.

Application to Tritium Removal

Clearly, an exchange reaction, if it will proceed at a reasonable rate, can remove $\mathrm{T}$ from the gas produced from a nuclearly stimulated gas well. Data from the Gasbuggy Experiment 1 showed that, during the initial shut-in period, two of the main gaseous components were $\mathrm{CH}_{4}(30-40 \%)$ and $\mathrm{H}_{2}$ $(10-20 \%)$. The corresponding radioactive species, $\mathrm{CH}_{3} \mathrm{~T}$ and $\mathrm{HT}$, accounted for the majority of the $\mathrm{T}$ contamination. Consequently, subsequent discussions are concerned with these two gases, with the main emphasis placed on $\mathrm{CH}_{3} \mathrm{~T}$.

Exchange reactions (3)-(7) below, which involve only common chemicals, are worth considering for gas decontamination. Analogous reactions (except for reaction (7)), where $\mathrm{HT}$ replaces $\mathrm{CH}_{3} \mathrm{~T}$ should also be considered for decontamination. Both sets of reactions must be considered in a thorough decontamination study.

$$
\begin{aligned}
& \mathrm{CH}_{3} \mathrm{~T}(\mathrm{~g})+\mathrm{H}_{2} \mathrm{O}(\mathrm{l})=\mathrm{CH}_{4}(\mathrm{~g})+\mathrm{HTO}(\mathrm{l}) . \\
& \mathrm{CH}_{3} \mathrm{~T}(\mathrm{~g})+\mathrm{H}_{2} \mathrm{O}(\mathrm{g})=\mathrm{CH}_{4}(\mathrm{~g})+\mathrm{HTO}(\mathrm{g}) . \\
& \mathrm{CH}_{3} \mathrm{~T}(\mathrm{~g})+\mathrm{NH}_{3}(\mathrm{~g})=\mathrm{CH}_{4}(\mathrm{~g})+\mathrm{NH}_{2} \mathrm{~T}(\mathrm{~g}) . \\
& \mathrm{CH}_{3} \mathrm{~T}(\mathrm{~g})+\mathrm{H}_{2} \mathrm{~S}(\mathrm{~g})=\mathrm{CH}_{4}(\mathrm{~g})+\mathrm{HTS}(\mathrm{g}) . \\
& \mathrm{CH}_{3} \mathrm{~T}(\mathrm{~g})+\mathrm{H}_{2}(\mathrm{~g})=\mathrm{CH}_{4}(\mathrm{~g})+\mathrm{HT}(\mathrm{g}) .
\end{aligned}
$$

Glycol dryers, ${ }^{6}$ as used in natural gas processing, might be used in decontamination procedures by employing the ethylene glycol as a reactant:

$$
\mathrm{CH}_{3} \mathrm{~T}(\mathrm{~g})+\mathrm{C}_{2} \mathrm{H}_{6} \mathrm{O}_{2}(\ell)=\mathrm{CH}_{4}(\mathrm{~g})+\mathrm{C}_{2} \mathrm{H}_{5} \mathrm{TO}_{2}(\ell) \text {. }
$$

Reactions of a similar nature where the gas stream is passed through a bed of silicate rocks or through rocks containing metal hydroxides might also be employed. These reactions will not be considered further in this paper. 
If an exchange reaction proceeds at a reasonable rate, then separation can be accomplished by contacting the flowing gas with a stream of the other component moving in the opposite direction. Consider reaction (3); what water flow would be required?

Let

$\mathrm{A}=\mu \mathrm{Ci}$ of $\mathrm{CH}_{3} \mathrm{~T}$ per $\mathrm{ml}$ of produced gas,

$\mathrm{G}=$ gas flow rate, $\mathrm{ft}^{3} / \mathrm{day}$,

$\mathrm{W}=$ water flow rate, $\mathrm{ft}^{3} / \mathrm{day}$,

$(\mathrm{RPG})_{\mathrm{g}}=$ amount of $\mathrm{T}$ in gas, $\mu \mathrm{Ci} / \mathrm{cc}$,

$(\mathrm{RPG})_{\mathrm{W}}^{\mathrm{g}}=$ amount of $\mathrm{T}$ in water, $\mu \mathrm{Ci} / \mathrm{cc}$,

where (RPG) denotes Radiation Protection Guide.* Conservation of radioaclivity shows that

$$
W=\frac{\left[A-(R P G)_{g}\right] G}{(R P G)_{W}} \text {. }
$$

The order of magnitude of $\mathrm{CH}_{3} \mathrm{~T}$ in the gas during the shut-in period was $\sim 15 \mu \mathrm{Ci} / \mathrm{ft}^{3}$ or $\sim 5.3 \times 10^{-4} \mu \mathrm{Ci} / \mathrm{cc}$. The required water flow is, of course, a function of the values taken for $(R P G)_{g}$ and $(R P G)_{W}$. Since no values have been tabulated for natural gas, (RPG) ${ }_{\mathrm{g}}$ was $\mathrm{g}_{\text {taken }}$ as $(\mathrm{RPG})_{\mathrm{a}}$, the value for air, with $\mathrm{T}$ as $\mathrm{H}^{\mathrm{T}} \mathrm{O}$ and no dilution with uncontaminated gas or combustion products. No dilution of the waste water was considered. Results are tabulated in Table III.

Table III. Water flow required for production of 1 million cubic feet gas per day.

\begin{tabular}{llll}
\hline $\begin{array}{c}\text { Condition of } \\
\text { exposure }\end{array}$ & $\begin{array}{l}(\mathrm{RPG})_{\mathrm{g}}, \\
\mu \mathrm{Ci} / \mathrm{cc}\end{array}$ & $\begin{array}{l}(\mathrm{RPG})_{\mathrm{W}}, \\
\mu \mathrm{Ci} / \mathrm{cc}\end{array}$ & $\begin{array}{c}\text { Water flow, } \\
\mathrm{ft} 3 / \mathrm{day}\end{array}$ \\
\hline $\begin{array}{c}168 \text {-hr week, general } \\
\text { population, gas as HTO }\end{array}$ & $7 \times 10^{-8}$ & $1 \times 10^{-3}$ & $5.3 \times 10^{5}$ \\
$\begin{array}{c}40-\text { hr week, occupational, } \\
\text { gas as HTO }\end{array}$ & $5 \times 10^{-6}$ & $1 \times 10^{-1}$ & $5.3 \times 10^{5}$ \\
\hline
\end{tabular}

Number of Stages Required

Clearly, the gas can be decontaminated by countercurrent equilibrium between the gas and water, and a logical question is how many stages might be required for extraction of $\mathrm{T}$ into $\mathrm{H}_{2} \mathrm{O}$ ?

Exchange processes can be considered in terms of the single-stage separation factor, $\alpha$, defined as the abundance ratio (atoms desired isotope/atoms undesired isotope) in the heads (product) stream divided by the isotope abundance ratio in the tails (waste) stream. The separation factor can be related to the equilibrium constant, Keg, as shown below. If one considers reaction (3), defines $T$ as the "desired" isotope, and replaces activities by molar concentrations, he finds that

$$
\alpha(3)=\frac{\left[\mathrm{HTO}^{\mathrm{T} O}\right]}{2\left[\mathrm{H}_{2} \mathrm{O}\right]} / \frac{\left[\mathrm{CH}_{3} \mathrm{~T}\right]}{4\left[\mathrm{CH}_{4}\right]}=2 \mathrm{~K}_{\mathrm{eq}} \text {. }
$$

On the other hand, replacement of $\mathrm{CH}_{3} \mathrm{~T}$ by $\mathrm{HT}$ in reaction (4) gives reaction ( $\left.4^{\prime}\right)$ :

$$
\mathrm{HT}(\mathrm{g})+\mathrm{H}_{2} \mathrm{O}(\mathrm{g})=\mathrm{H}_{2}(\mathrm{~g})+\mathrm{HTO}(\mathrm{g}) \text {, }
$$

\footnotetext{
* (RPG) values taken from Standards for Protection Against Radiation, Code of Federal Regulations, Title 10, Chapter 1, Part 20 (U. S. Govt. Printing Office, Washington, D. C.) (Revised Jan. 1, 1969).
} 
and

$$
\alpha\left(4^{\prime}\right)=\mathrm{K}_{\mathrm{eq}}
$$

Alpha is then related to but not necessarily equal to $\mathrm{K}$

Values of $\alpha$ for many $\mathrm{T}$-containing compounds have been published, 7 and some appropriate values are listed in Table IV.

Table IV. Single-stage separation factors $(\alpha)$ for selected reactions involving tritium compounds (abstracted from Ref. 7).

\begin{tabular}{cl}
\hline Reaction & $\alpha$ \\
\hline $\mathrm{CH}_{3} \mathrm{~T}+\mathrm{H}_{2} \mathrm{O}=\mathrm{CH}_{4}+\mathrm{HTO}$ & 1.14 \\
$\mathrm{CH}_{3} \mathrm{~T}+\mathrm{NH}_{3}=\mathrm{CH}_{4}+\mathrm{NH}_{2} \mathrm{~T}$ & 1 \\
$\mathrm{CH}_{3} \mathrm{~T}+\mathrm{H}_{2} \mathrm{~S}=\mathrm{CH}_{4}+\mathrm{HTS}$ & 1 \\
$\mathrm{CH}_{3} \mathrm{~T}+\mathrm{H}_{2}=\mathrm{CH}_{4}+\mathrm{HT}$ & 0.17 \\
\hline
\end{tabular}

Consider the liquid-gas extraction unit shown in Fig. 1 and the cases listed in Table III. It can be shown that $\mathrm{m}$ of Fig. 1 and $\alpha$ are related by the formula

$$
\mathrm{m}=\frac{1.6 \times 10^{-3}}{\alpha}
$$
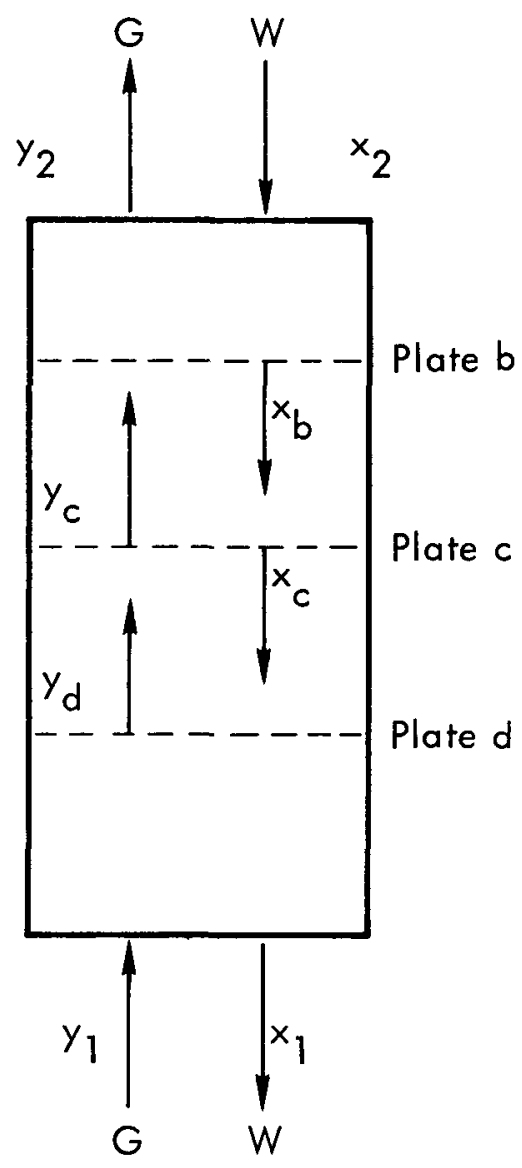

$$
\mathrm{G}=\text { volume of } \mathrm{CH}_{4} \text { flowing upward }
$$
(cu ft per day per unit area), $y=$ concentration of desired component in gas stream at any stage $(\mu \mathrm{Ci}$ of $\mathrm{CH}_{3} \mathrm{~T}$ per cu ft),

$$
W=\text { volume of } \mathrm{H}_{2} \mathrm{O} \text { flowing downward }
$$
(cu ft per day per unit area),

$x=$ concentration of desired component in liquid stream ( $\mu \mathrm{Ci}$ of HTO per cu ft).

Fig. 1. Symbols and parameters used in column design. (Treatment based on Sherwood and Pigford. ${ }^{8}$ ) 
for this particular reaction and system of units. Substitution of these data into equation (13) shows that only three or four plates are required in the cases considered.

Referring to Fig. 1, one sees that a material balance applied below plate c requires that

$$
W\left(x_{1}-x_{c}\right)=G\left(y_{1}-y_{d}\right)
$$

and a linear equilibrium relationship states that at any stage

$$
\mathrm{y}_{\mathrm{n}}=\mathrm{mx}_{\mathrm{n}} \text {. }
$$

The solution for the required number of plates, $N_{p}$, can be expressed as:

$$
N_{p}=\frac{\ln \left[\left(1-\frac{m G}{W}\right)\left(\frac{y_{1}-m x_{2}}{y_{2}-m x_{2}}\right)+\frac{m G}{W}\right]}{\ln (W / m G)} .
$$

Similar considerations apply to $\mathrm{HT}, \mathrm{C}_{2} \mathrm{H}_{5} \mathrm{~T}$, etc., but these reactions were not studied because of lack of time.

$\underline{\text { Reaction Rates }}$

These results show that if the previously discussed exchange reactions proceed at an acceptable rate, tritium decontamination is possible; however, the real question is whether or not the reactions proceed at a reasonable rate. A literature search showed no evidence for the homogeneous gas-phase exchange of either $\mathrm{D}$ or $\mathrm{T}$ between $\mathrm{H}_{2} \mathrm{O}$ and $\mathrm{CH}_{4}$. Recent data ${ }^{9}$ have verified that this homogeneous exchange does not occur in a mixture standing for 24 hours at $450^{\circ} \mathrm{C}$. These results are not surprising when the possible ratedetermining steps mentioned earlier are considered.

The exchange should occur by atomic interchange in the transition complex, and this behavior requires that the reaction take place either in aqueous solution with a homogeneous catalyst or in the gas phase with a heterogeneous catalyst.

Horiuti and Polanyi, 10 using Pt black or active Ni catalysts, found that the reaction

$$
\mathrm{C}_{2} \mathrm{H}_{4}(\mathrm{~g})+\mathrm{D}_{2} \mathrm{O}(\mathrm{g}) \rightleftharpoons \mathrm{C}_{2} \mathrm{H}_{2} \mathrm{D}_{2}(\mathrm{~g})+\mathrm{H}_{2} \mathrm{O}(\mathrm{g})
$$

reached equilibrium in 24 hours at $80^{\circ} \mathrm{C}$. The reaction

$$
\mathrm{C}_{6} \mathrm{H}_{6}(\mathrm{~g})+\mathrm{D}_{2} \mathrm{O}(\mathrm{g})=\mathrm{C}_{6} \mathrm{H}_{4} \mathrm{D}_{2}(\mathrm{~g})+\mathrm{H}_{2} \mathrm{O}(\mathrm{g})
$$

reached equilibrium after 2 hours at $200^{\circ} \mathrm{C}$, and the exchange between $\mathrm{C}_{6} \mathrm{H}_{6}$ and $\mathrm{H}_{2} \mathrm{O}$ was found to be $10^{5}$ times slower than $\mathrm{C}_{6} \mathrm{H}_{6}$ and $\mathrm{H}_{2}$ when both reactions were carried out over a $\mathrm{Ni}$ catalyst.

Extensive exchange studies with $\mathrm{CH}_{4}$ were conducted by Morikawa et al. 11-14 who reported that $\mathrm{CH}_{4}$ exchanged with $\mathrm{D}_{2}, \mathrm{CD}_{4}$, and $\mathrm{D}_{2} \mathrm{O}$ at $140^{\circ} \mathrm{C}$ and higher over an active $\mathrm{Ni}$ catalyst. The rates were in the order $\mathrm{CD}_{4}>\mathrm{D}_{2}>\mathrm{D}_{2} \mathrm{O}$. Clearly, $\mathrm{H}_{2} \mathrm{O}$ vapor and $\mathrm{CH}_{4}$ gas undergo catalytically induced $\mathrm{H}$ atom exchange.

The preparation of deuterated or tritiated organic compounds by direct exchange of the compound with $\mathrm{H}_{2} \mathrm{O}$ was pioneered by Garnett. 15 Platinum (II) oxide was employed as a catalyst; the procedure was most successful with aromatic compounds, but exchange occurred between $\mathrm{T}_{2} \mathrm{O}$ and a wide variety of alicyclic, aromatic, and aliphatic compounds. Rapid exchange was 
attributed to interaction between $\pi$-bonds of the aromatic molecules and $d$ orbitals of the $\mathrm{Pt}^{+2}$. Aliphatic hydrocarbons, containing only $\sigma$-bonds, underwent much slower exchange on the platinum surface. This procedure has now been extended to homogeneous systems 16 using $\mathrm{Na}_{2} \mathrm{PtCl}_{4}$ as a homogeneous catalyst, and compounds which are difficult to label in the heterogeneous system (e.g., nitrobenzene, bromobenzene, naphthalene, and acetophenone) have been labeled by the homogeneous method. A review of these methods has been published. 17

\section{KRYPTON REMOVAL}

Possible methods for $85 \mathrm{Kr}$ removal include (1) solution of $85 \mathrm{Kr}$ in $\mathrm{H}_{2} \mathrm{O}$, (2) chemical synthesis of a clathrate or a fluorine compound, and (3) use of the contaminated gas as feed material for ammonia synthesis.

The first of the se is ruled out because the solubility 18 of $\mathrm{Kr}$ in water is too small for effective removal during the exchange process. The second apperrs unpromising for the following reasons: Although the placing of large amounts of a fluorine-containing compound around the nuclear explosive used for gas well stimulation might have some potential for forming krypton fluoorides, the compounds $\mathrm{KrF}_{2}$ and $\mathrm{KrF}_{4}$ lack stability. 19 Clathrate compounds of $\mathrm{Kr}$ with phenol 20 and with $B$-hydroquinone 21,22 have been described, but in general these compounds have been made under high $\mathrm{Kr}$ pressures. Nothing is known about the stability of possible $\mathrm{Kr}$ compounds in the postshot environment.

The third method, use of the contaminated gas for ammonia synthesis, seems to have real potential. The normal process 23 for manufacturing ammonia synthesis gas starts with the partial oxidation of a hydrocarbon to a mixture of $\mathrm{CO}$ and $\mathrm{H}_{2}$. An iron catalyst then converts steam and $\mathrm{CO}$ to $\mathrm{H}_{2}$ and $\mathrm{CO}_{2}$; the gas is subsequently washed with water to remove $\mathrm{CO}_{2}$. Tritium can be removed from the $\mathrm{H}_{2}$ in this step by the reaction

$$
\mathrm{HT}(\mathrm{g})+\mathrm{H}_{2} \mathrm{O}(\ell)=\mathrm{H}_{2}(\mathrm{~g})+\mathrm{HTO}(\ell) \text {. }
$$

The gas is then passed through a tower countercurrent to liquid $\mathrm{N}_{2}$ which condenses $\mathrm{Ar}, \mathrm{CO}$, and residual $\mathrm{CH}_{4}$ and adds the required amount of $\mathrm{N}_{2}$ to the process stream. The $85 \mathrm{Kr}$ will be removed from the process stream at this point; however, it may be necessary to add inert $\mathrm{Kr}$ as a carrier.

\section{RECOMMENDATIONS}

The use of exchange reactions seems to have potential for decontamination of product gas, but this potential needs verification. A program to confirm the usefulness of this technique should include the following:

1. Equilibrium constants should be calculated for reactions (3) through (8), and their $\mathrm{H}_{2}$ counterparts, which offer potential means of removing the tritium.

2. Equilibrium data plus reasonable flow data should be employed in preparing a preliminary reference design for such a possible separation plant. A cost estimate should be made.

3. Use of the gas for ammonia synthesis should be examined carefully, since this appears to be a promising way to remove the ${ }^{85} \mathrm{Kr}$.

4. Experimental work on the rates of these reactions should be started. Can the ruaction be made to go with liquid water? Is a catalyst necessary? Is the catalyst poisoned by liquid water, thereby requiring that the reactions be run in the vapor phase?

5. An effort should be made to set some standards for radioactivity in natural gas. This is a difficult question, but without standards it is impossible to do practical planning for nuclear stimulation of gas wells. 


\section{ACKNOWLEDGMENTS}

This work was done under the auspices of the U. S. Atomic Energy Commission, while the author was a summer employee at Lawrence Radiation Laboratory. It is a pleasure to acknowledge the aid of $\mathrm{R}$. W. Taylor, Charles F. Smith, Howard A. Tewes, and Edward L. Lee. Norman Bonner, Howard Tewes, and Albert E. Sherwood reviewed this manuscript; the author is grateful for their aid.

\section{REFERENCES}

1. Charles F. Smith, Jr., Project Gasbuggy Gas Quality Analysis and Evaluation Program Tabulation of Radiochemical and Chemical Analytical

Results, Lawrence Radiation Laboratory, Livermore, Report

UCRL-50635 (April 22, 1969).

2. H. Urey, J. Chem. Soc., 562 (1947).

3. J. Bigeleisen, J. Chem. Phys. 17, 675 (1949).

4. J. Bigeleisen, Isotopic Exchange Reactions and Chemical KineticsBrookhaven Conference Report, Brookhaven National Laboratory Rept. $53(1948)$.

5. K. E. Wilzbach, J. Am. Chem. Soc. 79, 1013 (1957).

6. Charles Bowman, El Paso Natural Gas Co., private communication (July 23, 1969).

7. Ya. M. Barshabskii, in Tritium in the Physical and Biological Sciences (International Atomic Energy Agency, Vienna, 1962), vol. 1, pp. 169-177.

8. Thomas K. Sherwood and Robert L. Pigford, Absorption and Extraction (McGraw-Hill Book Co., New York, 1952), 2nd ed., pp. 144-148.

9. Preston Gant and Kim Yang, Continental Oil Co., private communication (July 24, 1969).

10. Jumo Horiuti and M. Polanyi, Trans. Faraday Soc. 30, 1164 (1934).

11. K. Morikawa, W. S. Benedict, and H. S. Taylor, J. Am. Chem. Soc. 57, 592 (1935).

12. K. Morikawa, W. S. Benedict, and H. S. Taylor, J. Am. Chem. Soc. $\underline{58}$, 1445 (1936).

13. K. Morikawa, W. S. Benedict, and H. S. Taylor, J. Am. Chem. Soc. 58, 1795 (1936).

14. K. Morikawa, N. R. Trenner, and H. S. Taylor, J. Am. Chem. Soc. 59, $1103(1937)$.

15. J. L. Garnett, Nucleonics 20 (12), 86 (1962).

16. J. L. Garnett and R. J. Hodges, Chemical Communications, 1001 (1967).

17. J. L. Garnett and W. A. Sollich-Baumgartner, Advances in Catalysis (Academic Press, New York, 1966), vol. 16, p. 95.

18. Handbook of Chemistry and Physics, Charles D. Hodgman, Editor (Chemical Rubber Publishing Co., Cleveland, Ohio, 1955), 37th ed., p. 1608.

19. G. J. Moody and J. D. R. Thomas, Noble Gases and Their Compounds (Macmillan, New York, 1964).

20. P. H. Lahr and H. L. Williams, J. Phys. Chem. 63, 1432 (1959).

21. M. M. Hagan, J. Chem. Educ. 40, 643 (1963).

22. J. W. McClain and W. S. Diethorn, J. Appl. Radiation Isotopes 14 (10), 527 (1963).

23. Marshall Sihig, Inorganic Chemical and Metallurgical Process Encyclopedia (Noyes Development Corp., Park Ridge, New Jersey, 1968), p. 56. 


\section{$\underline{\text { L RL Internal Distribution }}$}

Michael M. May

J) Sewell

R. E. Batzel

A. Biehl

J. W. Gofman

A. C. Haussmann

C. A. McDonald

W. E. Nervik

II. L. Reynolds/P. E. Coyle

J. W. Rosengren

E. Teller

G. C. Werth

J. E. Carothers

D. W. Dorn

G. D. Dorough

F. S. Eby

E. H. Fleming

W. B. Harford

G. H. Higgins

F. Holzer

J. S. Kahn

J. T. Cherry

J. S. Kane

J. B. Knox

M. Heinberg

M. D. Nordyke

W. E. Vandenberg

T. Perlman

P. H. Moulthrop

J. Toman

B. Rubin

P. C. Stevenson

H. A. Tewes

R. W. Taylor

C. F. Smith

E. L. Lee

N. A. Bonner

A. E. Sherwood

D. D. Rabb

L. Crooks/E. Harp, Mercury TID Berkeley

TID File 
J. A. Wethington, Jr.

University of Florida

Gainesville, Florida

C. D. Broyles

W. D. Weart

L. J. Vortman

J. W. Reed

C. W. Gulick

M. L. Merritt

Sandia Laboratories

Albuquerque, New Mexico

J. O. Putman

Space and Missile Systems Organization

Norton Air Force Base, California

Division of Technical Information Extension, Oak Ridge

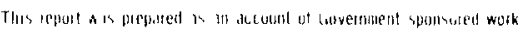

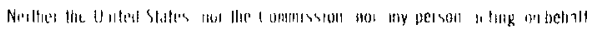
of thi Collen ISStem

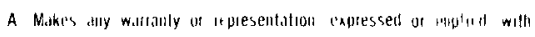

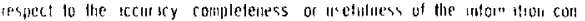

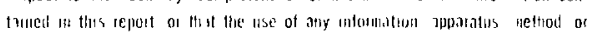

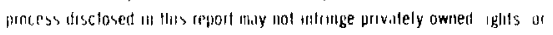

B Assumes any hablulties with respect lo the use of an for dianages

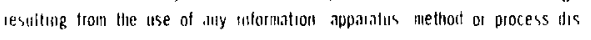
clossit in this seport

As used iu the ahove "person acturg on heltall of the Conmussion" inclutes any employec of contraclor of the Contumission or employee of such contractor to the extent that such employee or contractor of the Cothnlission ur employee of such contuctor prepares dissemimates or provides arcess to any inforination pursuant to lims employment ar conliac! with the Commission or his eltaploynlent with suscli contractor

$\mathrm{WC} / \mathrm{dh}$ 